\title{
THE SOCIAL SECURITY ACT AND THE BLIND
}

\author{
Robert B. Irwin* and Evelyn C. McKay†
}

Special legislation providing relief to the needy blind in the form of direct financial assistance from public funds has about seventy years of history in the United States. The first provision of this type is found in a resolution passed in 1866 by the Board of Aldermen and Board of Councilmen of New York City, establishing a definite procedure for dealing with applications from blind persons for "donations" from city funds. From this early resolution developed the provision in the New York City Charter under which special relief to the blind is still administered.

The first effort at state legislation for relief for the blind was in Ohio, where in 1898 a law was enacted for this purpose, the administration being placed in the hands of the township trustees. This law was later declared unconstitutional, and a new act which replaced it in 1904 was likewise ruled out by the State Supreme Court. Finally in 1908 a law was enacted by the legislature which triumphantly passed the test of constitutionality and established the principle of relief for the blind from public funds.

In the meantime the legislature of Illinois had, in 1903, enacted a so-called "blind pension law," and the precedent of blind relief hàving thus become firmly established, other states followed, one by one, until, by January, 1935, 26 states and the City of New York had made special financial provision from public monies for their needy blind people.

The theory on which blind relief legislation is based is that blindness itself is a sufficiently well-defined cause of poverty to require special consideration at the hands of the state. The blind people themselves have been especially active in initiating and promoting such legislation since they feel that a special allowance, made in consideration of their handicap, is free from the stigma commonly attached to "poor relief," and moreover that, by the setting up of special administrative provisions, they

- B.A., 1906, University of Washington; M.A., 1907, Harvard University. Director, Bureau of Research, 1923-1929, and Executive Director since 1929, American Foundation for the Blind, New York. Supervisor of classes for the blind and sight-saving classes in various cities of Ohio, 1915-1923. Co-author, Blind Relief Laws and Their Administration in the United States (1919), Blind Relief Laws, Their Theory and Practice (1929); author of various pamphlets and articles on work for the blind.

† B.A., 1919, University of British Columbia; graduate study, Bryn Mawr College and University of California. Research Agent, American Foundation for the Blind, since 1926; Associate Editor, Outlook for the Blind, since 193r. Engaged in industrial management work for two years; work in public health statistics for two years. Co-author, Blind Relief Laws, Their Theory and Practice (1929); author of various articles on work for the blind. 
are spared the humiliation of investigation by the poor relief authorities who, they feel, do not understand the special needs and problems of blind people.

Some persons hold the opinion that such special allowances are a sort of compensation for blindness and that all blind persons should be entitled to them regardless of need. In this connection the allowance is often termed a "pension." The majority of workers for the blind and many thoughtful blind people, however, oppose this point of view on the grounds that the "pension" discourages industry and tends to pauperize the blind individual and that the taxpayer cannot be expected and should not be asked to contribute to the income of those who can maintain themselves without such assistance. Moreover, to provide a "pension" of adequate amount for all blind persons regardless of need would require such vast expenditures from public funds that the taxpayers would in time rebel and might repudiate the whole idea of special public assistance to the blind. Those who take this position advocate the administration of such special allowances on the basis of need and term them "blind relief."

The terms "aid for the blind" and "assistance to the blind" have not been in common usage in this connection, possibly because of the danger of confusion with another type of state assistance to the blind-namely, the services rendered by state departments or "commissions" for the blind.

\section{SeRvices to THE BLIND}

From the beginning of organized work for the blind in the United States early in the nineteenth century it has been the aim of the friends of the blind to render them self-supporting so far as possible. The first step was the education of the young blind; then the establishment of special workshops where capable blind people were given employment; then the teaching of embossed print and handicrafts to adult blind people in their homes. At first these activities were in the hands of voluntary agencies, financed by philanthropic private citizens, but gradually their usefulness was accorded recognition by the state. In 1906 the first "Commission for the Blind" was established by act of the Massachusetts legislature-a state agency, supported from public funds for the purpose of locating blind persons, providing vocational training and employment for them according to their capacities, teaching them the use of embossed print, and helping the newly-blinded to adjust themselves to their handicap.

This was.the beginning of a renaissance of interest in the blind, and, during the next 25 years, $25^{1}$ additional state departments for the blind came into being with powers as broad as those defined above, their purpose being to promote the welfare of the blind as independent, activc, participating members of society. The recent depression and the resultant pressure on state legislatures to reduce expenditures, however, temporarily halted the development of this constructive program. Budgets

\footnotetext{
1 Two other states (Florida and Nebraska) had passed legislation to establish such state departments for the blind but had made no appropriation.
} 
were severely cut, particularly in some states where the work was in its infancy, and no new commissions for the blind were established in the states which had not previously made such provisions. 'Yet the needs of the blind people for eye care, employment, and social adjustment were intensified by the depression.

\section{The Development of Provisions for the Blind in the Social Securrty Act}

In January, 1935, when the Social Security Act was introduced in Congress, workers for the blind saw, in the section providing federal funds for assistance to states in their programs for crippled children, what appeared to be a solution for this problem of inadequate support for state programs for the social and vocational adjustment of the blind. An amendment to the Act was drafted, which provided for federal funds to the extent of $\$ 1,500,000$ to be used for assistance to the states for their expenditures for diagnosis and treatment of eye conditions, vocational training, employment, home teaching, and other social service, and for special appliances and equipment used in the education, employment, and recreation of the blind. This amendment was laid before the Senate Finance Committee and workers for the blind united to secure support for it. The Senate Finance Committee, however, incorporated in the Act when they reported it back to the Senate, not this amendment but another (the present Title $\mathrm{X}$ ) providing $\$ 3,000,000$ for federal aid to the states in their programs of "aid to the blind," this term being defined to mean "money payments to needy blind persons." Whereas the original amendment had followed closely the wording of the provision for crippled children (Title V, Part 2), the substitute amendment was drafted along lines similar to those of Title I providing old-age assistance, a circumstance which exemplifies the wide difference in the concepts which lie back of the two amendments.

Senator Robert F. Wagner, sponsor of the Social Security Bill, offered another amendment from the floor of the Senate, providing that half of the proposed sum of $\$ 3,000,000$ be used for reimbursement of state expenditures for "locating blind persons, providing diagnoses of their eye conditions, and for training and employment of the adult blind." This amendment passed the Senate but was stricken out by the Joint Conference Committee of House and Senate to which the Bill was referred. In the final form of the Act the use of federal funds was limited to reimbursements for state programs of blind relief.

This brief sketch of the origin and history of Title $\mathrm{X}$ has been presented because of the light it throws on the problems involved in the administration of aid to the blind under the Act. Supporters of the original amendment believe that the primary consideration in the welfare of the blind is their restoration to social and economic independence, either by improvement or restoration of vision through proper medical care, or, if blindness is irremediable, through vocational training, employment, instruction of the adult blind in their homes, and adjustment of the newly-blinded to 
their handicap. Financial relief is but one phase of such a program, to be resorted to only as a temporary measure, or when all else fails.

The concept behind Title $\mathrm{X}$, however, is that dependency is the general lot of the blind and monetary relief their primary need.

\section{The Provisions of Titze $\mathrm{X}$}

Title $\mathrm{X}$ authorizes the appropriation of the sum of $\$ 3,000,000$ of federal funds for the fiscal year ending June 30,1936 and, in each fiscal year thereafter, so much as may be necessary for assistance to the states through reimbursement for 'one-half of the state's expenditưres for aid to the blind (but the federal grant shall not exceed \$15 on behalf of any one blind person). In order to be eligible for federal funds, a state must have in effect a state program of relief to the blind which is found by the Federal Social Security Board to meet the following requirements specified in Section I002 of the Federal Act:

"(a) A State plan for aid to the blind must

(I) Provide that it shall be in effect in all political subdivisions of the State, and, if ad. ministered by them, be mandatory upon them;

(2) Provide for financial participation by the State;

(3) Either provide for the establishment or designation of a single State agency to administer the plan, or provide for the establishment or designation of a single State agency to supervise the administration of the plan;

(4) Provide for granting to any individual, whose claim for aid is denied, an opportunity for a fair hearing before such State agency;

(5) Provide such methods of administration (other than those relating to selection, tenure of office, and compensation of personnel) as are found by the Board to be neces. sary for the efficient operation of the plan;

(6) Provide that the State agency will make such reports, in such form and containing such information, as the Board may from time to time require, and comply with such provisions as the Board may from time to time find necessary to assure the correctness and verification of such reports;

(7) Provide that no aid will be furnished any individual under the plan with respect to any period with respect to which he is receiving old-age assistance under the State plan approved under section 2 of this Act.

"(b) The Board shall approve any plan which fulfills the conditions specified in subsection (a), except that it shall not approve any plan which imposes, as a condition of eligibility for aid to the blind under the plan-

(r) Any residence requirement which excludes any resident of the State who has resided therein five years during the nine years immediately preceding the application for aid and has resided therein continuously for one year immediately preceding the application; or

(2) Any citizenship requirement which excludes any citizen of the United States."

It is of interest to note that on May I7 when the Social Security Act, with Title X included, was reported back to the Senate, 26 states $^{2}$ had programs of relief to the

'Florida, Indiana, Oklahoma and the District of Columbia enacted blind relief legislation in 1935, which did not take effect until later. 
needy blind in effect but not one of these programs met the requirements of the Federal Act. Some were rendered ineligible by the stringency of their residence requirements, some by the fact that the blind relief was administered by the counties without supervision of a state agency, some by the fact that the relief law was not state-wide and mandatory on the counties, some because there was no financial participation by the state. Two states, Massachusetts and Connecticut, in which relief for the blind was administered under a general clause in the law which established the state department for the blind, found that they would be able to qualify by changes in the rules and regulations of the state department; but the remaining 24 state laws required legislative action to bring to them into conformity with the provisions of the Federal Act.

New Hampshire was the first state to take action, and, in June, 1935, (before the Social Security Act had been fully passed by Congress) the necessary amendments to its laws were enacted. Other states, one by one, hastened to make themselves eligible for the anticipated federal aid, either by amending existing laws or by passing new legislation.

On February 12, 1936, one day after Congress had passed the necessary appropriation, II states (Arizona, Connecticut, Idaho, Maine, Mississippi, Nebraska, New Hampshire, North Carolina, Pennsylvania, Wisconsin and Wyoming) and the District of Columbia, having had their programs of blind relief approved by the Social Security Board, received their first quarterly allotments.

\section{Eligrbility of Blind Persons to Receive Aid}

It is to be noted that the federal act imposes no restrictions upon the states as to the qualifications for eligibility for the relief grants, except in the case of residence. Each state is left free to establish its own definition of blindness and its own definition of need.

There are wide variations among the various state laws on both these points. The definition of blindness, for instance, ranges from the restricted "not more than light perception," in the Missouri law, to the somewhat general "inability, by reason of loss of eyesight, to provide oneself with the necessities of life," which with slight variations, is found in the laws of fifteen states, among them California, New Jersey, and Ohio. In general this phrase is interpreted to mean " $20 / 200$ visual acuity or less in the better eye," but its flexibility permits allowance to be made for those whose visual handicap is due to restriction of the field of vision rather than to loss of visual acuity.

The differences in definition of need are even more striking. While more than half the states define need in general terms such as "inability to provide oneself with the necessities of life" there are a few notable exceptions. Some states define a needy individual as one whose yearly income is less than a specified amount. The Pennsylvania law of 1935 , for instance, provides that any blind person whose annual income 
is less than $\$ 840$ shall receive an allowance of $\$ 360$ a year, and any blind person whose income exceeds $\$ 840$ shall receive a grant sufficient to bring his total annual income up to $\$ 1,200$ per year. While this is the most liberal income allowance provided for in any of the states, a number of other states have adopted the same principle of defining need in terms of income.

In this connection should be noted the differences in the amounts of relief grants to be paid. While most states provide that the amount of the allowance shall be adjusted to the needs of the individual, with specified maximums ranging from \$150 to $\$ 600$ per year, three states (Illinois, Missouri, and Pennsylvania) specify in their laws the amount to be granted ( $\$ 300$ to $\$ 365$ per year) to all eligible applicants alike, without regard to need.

These variations in definition of blindness, definition of need, and principle of determining the amount of the grant will doubtless be reflected in the relief expenditures for the various states, but it is not yet possible to foretell what administrative problems will result from this situation. Although the Social Security Board has power to supervise to a certain extent the administration of the state plans, it has no power to require changes in the state requirements for eligibility, and it may be that the lion's share of the federal funds will go to those states which expend the greatest amount for blind relief, not to those which, through administration on a case-work basis, are striving to provide adequate relief at reasonable cost.

\section{Recommended Blind Relief Legislation}

After observation of the experience of the various states in administering their blind relief laws during the past thirty years, many workers for the blind have come to believe that blind relief is most satisfactory when it is administered by a state agency as part of the total program for the welfare of the blind. This makes it possible to utilize the relief grants as supplementary aid during a period of vocational adjustment, to restore to the sighted world and to economic independence many who are unnecessarily blind through ignorance or neglect, and to prevent the abuse of the relief law by those who could, if they would, support themselves by their own efforts. Relief administered independently of such a program tends to pauperize the blind, to discourage industry and to add to the relief rolls many who need not be receiving public assistance.

Other provisions which experience has demonstrated to be desirable in a blind relief law are:

Administration by a state agency to insure uniformity of policy;

Partial financial responsibility by the counties to ensure local interest and a feeling of responsibility for the blind in the community;

Administration on a sliding scale on the basis of individual need, to ensure adequate provision for those who have no other resources and at the same time prevent an undue burden on the taxpayers; 
A flexible definition of blindness which can be interpreted on the basis of the practical usefulness of any remaining vision rather than on a hard-and-fast measurement of visual acuity;

The use of relief funds for restoration of vision or for vocational training in order to reduce dependency wherever possible.

None of these recommendations are inconsistent with the requirements of the Social Security Act, except for the fact that federal funds cannot be used to reimburse grants made for medical service or vocational training.

\section{Relation of Aid to the Blind to Other Types of Special Allowance}

There is unfortunately a disposition on the part of legislators and public welfare officials to regard the dependency of the blind as comparable to the dependency of the aged or of widows and orphans, and to administer all three types of special allowance in the same department. The fact that the Social Security Act makes specific provision for all three types of aid in almost identical terms increases this tendency, for in the scramble for federal funds it is obviously easier to draft and enact one state plan which meets the federal requirements than to develop three separate plans individually suited to the needs of the respective groups.

The fallacy of this procedure, however, is apparent to those who are familiar with the problems of blind people. For the aged the hope of regaining economic independence is very slight; what they desire is an allowance which will provide the maximum of security for their remaining years. For widows and orphans the acute need is usually temporary, and aid will be required only until the children attain adulthood and take their normal places in the economic world.

The blind, however, are a heterogeneous group in which are included representatives of all age groups, and all levels of ability. For a large proportion of them the regaining of economic independence is possible provided they have the necessary training and assistance in adjusting themselves to their handicap. They are not necessarily permanent dependents like the aged except when age or ill-health combines with blindness to make them so; nor are they temporary dependents, as are orphans who in a few years achieve maturity and take their normal places in the economic world. The truth is that whether the dependency of the blind is permanent or temporary depends upon the extent to which special services for medical care, education, and vocational adjustment are available to them in the community.

Any plan for the administration of blind relief which fails to take into consideration these factors can only increase dependency and stultify initiative.

The friends of the blind are therefore hoping most urgently that the new state plans for aid to the blind will be developed in close coördination with a constructive program for the blind, preferably by placing the administration in the hands of a stite department responsible for all phases of the welfare of the blind, or, where this is impossible, establishing an active inter-relationship between the relief division and the state department for the blind. 
Since fifteen states have no state-supported work for the adult blind, and in several others the financing of such work is highly inadequate, the problems involved in setting up such relationships are serious. Yet the extension of such constructive services as a complement to the blind relief program is essential if the blind citizens of these states are not to be condemned to lives of idleness and listless dependency by the very law which sought to help them.

In conclusion it may be said that the aid to the blind, provided by the Social Security Act, will bring great benefits to thousands of blind people throughout the country, particularly in those states where heretofore no legislative provision for blind relief had been made or where local funds have been inadequate for the purpose. But, if the result of this federal aid is to discourage the blind from efforts to be selfsupporting, to deter employers from employing capable blind persons and to produce in the minds of the seeing public the false impression that "the blind are now taken care of," the Act will do more harm than good. It is to be hoped that those in charge of public policy will recognize the program of federal aid for what it is-the first step in developing a well-rounded program for the welfare of the blind-and will shape federal and state plans accordingly, to the end that the blind people of this country may take their proper places as independent self-respecting members of the community. 